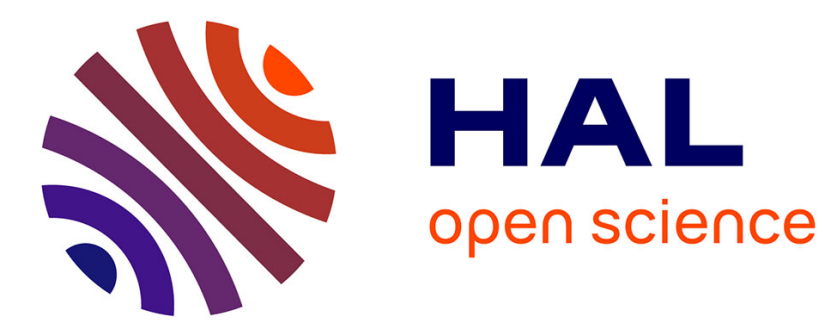

\title{
Influence of geomorphological constraints and exploitation techniques on stone quarry spatial organisation
}

Alain Devos, Gilles Fronteau, Olivier Lejeune, Christelle Sosson, Edith Chopin, Vincent Barbin

\section{To cite this version:}

Alain Devos, Gilles Fronteau, Olivier Lejeune, Christelle Sosson, Edith Chopin, et al.. Influence of geomorphological constraints and exploitation techniques on stone quarry spatial organisation. Engineering Geology, 2010, 115 (3-4), pp.268-275. 10.1016/j.enggeo.2010.05.004 . hal-01689090

\section{HAL Id: hal-01689090 https://hal.science/hal-01689090}

Submitted on 26 Jan 2018

HAL is a multi-disciplinary open access archive for the deposit and dissemination of scientific research documents, whether they are published or not. The documents may come from teaching and research institutions in France or abroad, or from public or private research centers.
L'archive ouverte pluridisciplinaire HAL, est destinée au dépôt et à la diffusion de documents scientifiques de niveau recherche, publiés ou non, émanant des établissements d'enseignement et de recherche français ou étrangers, des laboratoires publics ou privés. 
Devos, A., Fronteau G., Lejeune, O., Sosson, C., Chopin, E., and Barbin, V., 2010, Influence of geomorphological constraints and exploitation techniques on stone quarry spatial organisation. Example of Lutetian underground quarries in Rheims, Laon and Soissons areas. Engineering Geology, vol. 115. p. 268-275. doi:10.1016/j.enggeo.2010.05.004.

\section{Influence of geomorphological constraints and exploitation techniques on stone quarry spatial organization. Example of Lutetian underground quarries in Rheims, Laon and Soissons areas}

Alain Devos ${ }^{a}$, Gilles Fronteau ${ }^{a}$, Olivier Lejeune ${ }^{a}$, Christelle Sosson ${ }^{a}$, Edith Chopin ${ }^{b}$, Vincent Barbin ${ }^{a}$

a: EA 3795 GEGENAA, Université de Reims Champagne-Ardenne, France

b: Oakland University, Department of Chemistry, Rochester, MI 48309, USA

E-mail addresses: alain.devos@univ-reims.fr (A. Devos), gilles.fronteau@univ-reims.fr (G. Fronteau), olivier.lejeune@univ-reims.fr (O. Lejeune), christelle.sosson@univ-reims.fr (C. Sosson), chopin@oakland.edu (E. Chopin), vincent.barbin@univ-reims.fr (V. Barbin).

\section{Abstract}

The Lutetian limestones were used to build numerous historical monuments in the north-east part of France. In Rheims, Laon and Soissons areas more than 400 underground quarries have been inventoried, by research in the regional archives, on old maps and by several months of ground prospecting. Actually, most of these underground quarries are abandoned. Only 3 are now open, in the Soissons area. In the Rheims region, the last active quarry, located at Courville village, was closed in 2005, because of the safety conditions.

The aim of the study was to demonstrate the importance of geomorphological context on the fracturing network and on the quarry spatial organisation. Underground topography, fracturing network measurement, aerial mapping and analysis of the geomorphological features show the high connection between natural constraints and extraction choices and may explain the progressive disappearance of building stone quarries in a part of the studied area.

In the east of the studied area, where the usable limestone has a weak thickness and important mechanical distension stress, the galleries direction depends on fracturing network. In contrast, in the west (Soissons area), limestone shows thick homogeneous facies that allow a rational extraction using room and pillars mining system.

Keywords: Eastern France, Lutetian, Limestone, Underground quarries, Fracturing network.

\section{Introduction}

The studied area is located in North-East France, between Rheims and Paris. Here, numerous historical buildings (gothic cathedrals, abbeys, episcopal palaces, medieval city walls, citadels and castles) can be found in the Rheims, Laon and Soissons areas (Fig. 1). Rheims was the capital of the Roman Gallia Belgica province and, later on it became the French kings' coronation city, while Soissons was the capital of the Franks and Laon was a Carolingian capital.

Main buildings were built using Lutetian limestones from nearby underground quarries. Need for limestone remained important until the 1920's due to post-WWI reconstruction (Devos et al., 2008).

Although stone quarries were numerous in the area: more than 400 have been inventoried, they are now all closed. In the Rheims area, the last open underground quarry was closed in 2005, at Courville. Only 3 underground quarries are being exploited today at Bonneuil-en-Valois, Vassens and at Saint-Pierre-Aigle. As old quarry locations are often unknown, restoration using the appropriate stones is difficult.

The geomorphological context is particular: the valleys (Aisne and Vesle River), cut into the Tertiary limestone plateau, which forms the Cuesta of île de France (Fig. 1). The base of this cuesta is formed by clays and sands of Thanetian and Ypresian (Pomerol and Feugueur, 1974). The marine limestone of the middle Lutetian (Calcaires grossiers), follows and composes the structural backslope of the cuesta. The upper Lutetian, made by lacustrine marl and limestone, covers these layers. A few centimetres toseveral metersof quaternary lösscan befound on the surface of the tertiary plateaus.Post-Lutetianformationswere deposited in fresh-water orshallowmarineenvironmentsin 
Devos, A., Fronteau G., Lejeune, O., Sosson, C., Chopin, E., and Barbin, V., 2010, Influence of geomorphological constraints and exploitation techniques on stone quarry spatial organisation. Example of Lutetian underground quarries in Rheims, Laon and Soissons areas. Engineering Geology, vol. 115. p. 268-275. doi:10.1016/j.enggeo.2010.05.004.

Tardenois, Orxois and Brie regions (south of the study area; Fig. 1). They formed a thick sand-clay-limestone-gypsum cover on top of the Lutetian limestone. This cover did not exist in Soissonnais and Laonnois regions.

As the Lutetian sea shoreline was located in the Rheims region (Gely, 1996, 1998; Blary et al., 2004; Gely et al., 2009), to the west, in the Soissonnais area, marine conditions and chemical sedimentation occurred with development of limestone and dolomite, giving a stratigraphic column two times thicker than in the Rheims area. So, the facies rapidly change laterally and vertically in the east (Rheims region), while they remained homogenous in the Soissonnais and Laonnois areas (Fronteau et al., 2010). In a similar way, bank thickness greatly decreased, from $40 \mathrm{~m}$

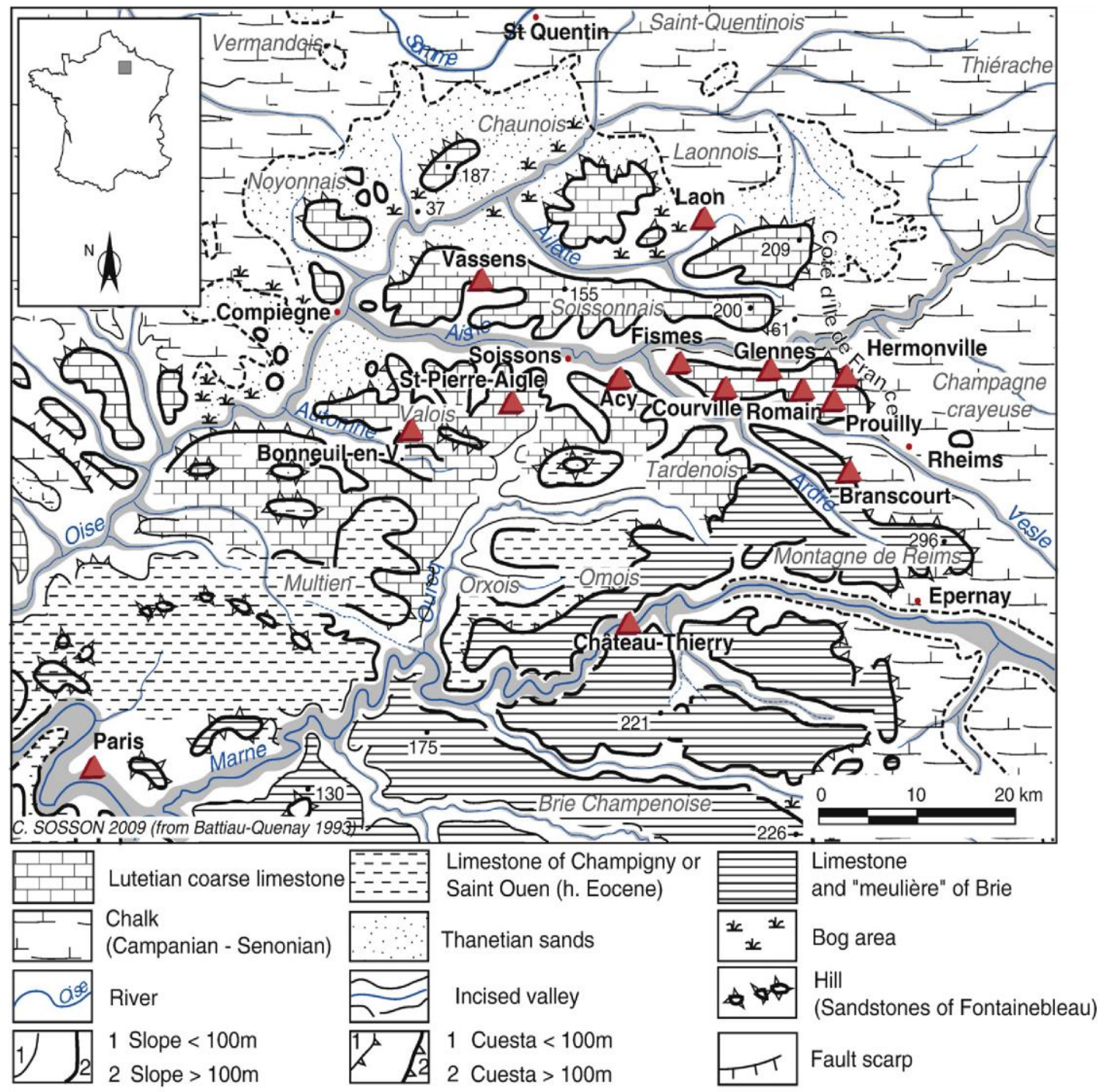

- Town $\quad \Delta$ Underground quarry Orxois Country ("Pays") $1 \dot{75}$ Altitude (meters)

Fig. 1. Location map.in the Soissonnais area to $15-20 \mathrm{~m}$ in the Rheims and Laonnois areas.

In the east of the studied area, usable banks were thin (less than $1 \mathrm{~m}$ ), discontinuous and bound by unusable formations and easily weathered banks (Fronteau, 2000; Fronteau et al., 2002). These characteristics hinder quarry development by reducing their profitability and geotechnical stability (Pelizza et al., 2000). That may explain the reasons why all quarries were closed earlier in the Rheims area, while few remain active in the middle of the Paris basin (Vassens, Saint-Pierre-Aigle, and Bonneuil-en-Valois).

Moreover, the Aisne hydrographic network was well developed in the Soissonnais and Laonnois areas. In these two regions, hydrographic network, highly developed during the Pleistocene epoch, led to the incision of the geological 
Devos, A., Fronteau G., Lejeune, O., Sosson, C., Chopin, E., and Barbin, V., 2010, Influence of geomorphological constraints and exploitation techniques on stone quarry spatial organisation. Example of Lutetian underground quarries in Rheims, Laon and Soissons areas. Engineering Geology, vol. 115. p. 268-275. doi:10.1016/j.enggeo.2010.05.004.

formations and increased the number of Lutetian limestone outcrops. Therefore, because of these different reasons, more quarries were found in the northern part of the study area, than in the south-eastern part (Fig. 1).

The extraction sites inventory was compiled from bibliography (Dolfini, 1920; Montagne, 1998; Mauvais, 2004; Lachaux, 2005; Sosson et al., 2009), geological maps, underground database and fieldwork, by searching in the Regional Archives, and by several months of prospections on the ground. Thirty five out of the 400 underground quarries were studied and 12 were mapped using compass and lasermeter during topographic progression or from a central point. This determined the spatial organisation of the quarries. Moreover, the fracturing network was measured (with its orientation, width and possible fillings). Karstic forms may be found on the topographies, (in this case, samples of the fillings were taken to be examined in laboratory). Finally, evidence from quarrying tools was analysed to determine exploitation direction (Jaillet et al., 2002).

The purpose of this study is to show the fundamental part of fissural and geomorphological constraints on the Lutetian limestones underground exploitation. The study of the fracturing network lets us understand spatial organization of the quarries, and the processes which represent a constraint to the exploitation.

\subsection{Fissural and geomorphological constraints on the borders of the slopes}

\subsubsection{Fracturing directions}

The fracturing measurements made in the underground quarries of 11 settings allow a statistical analysis of their distribution (Fig. 2). They are mainly organized by the orientation of the slopes of the main valley (N125 for Vesle between Rheims and Fismes and $\mathrm{N} 160^{\circ}$ downstream of Fismes) and secondarily by the tributary orthogonal valleys $\left(\mathrm{N} 40^{\circ}\right.$ and $\left.\mathrm{N} 90^{\circ}\right)$. Their course is parallel to the contour lines.
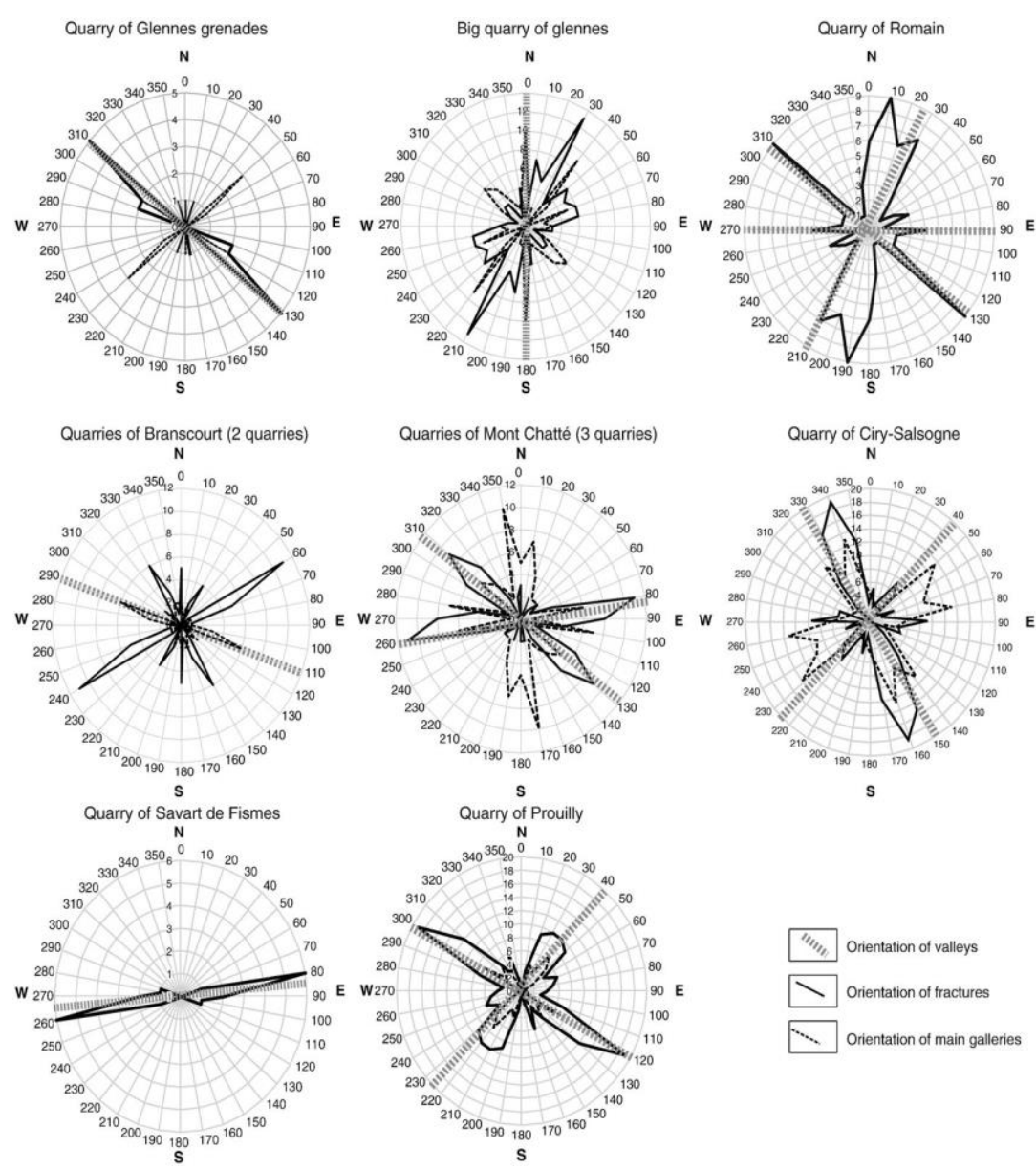

Quarry of Ciry-Salsogne
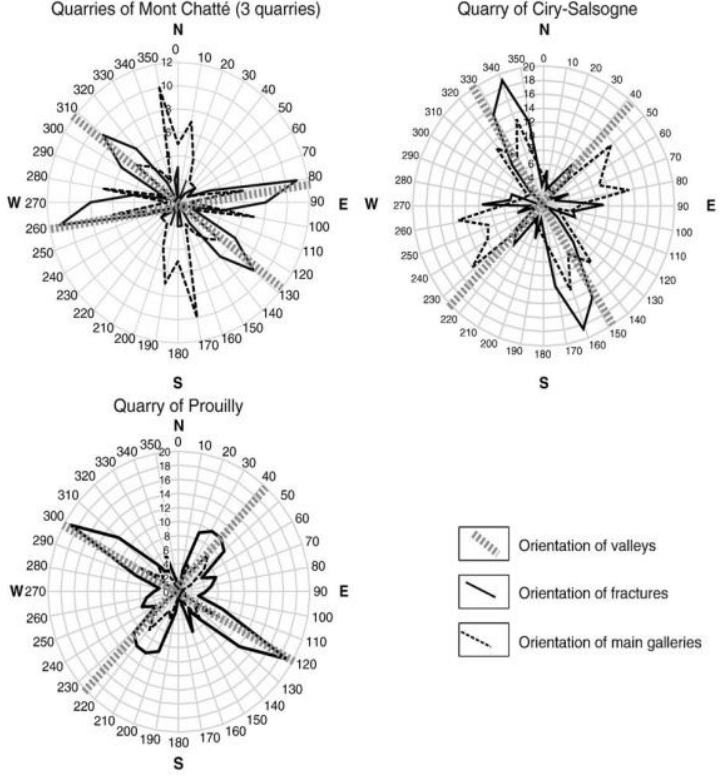

Fig. 2. Comparison between the adits direction, fracture network and hillslope aspect 
Devos, A., Fronteau G., Lejeune, O., Sosson, C., Chopin, E., and Barbin, V., 2010, Influence of geomorphological constraints and exploitation techniques on stone quarry spatial organisation. Example of Lutetian underground quarries in Rheims, Laon and Soissons areas. Engineering Geology, vol. 115. p. 268-275. doi:10.1016/j.enggeo.2010.05.004.

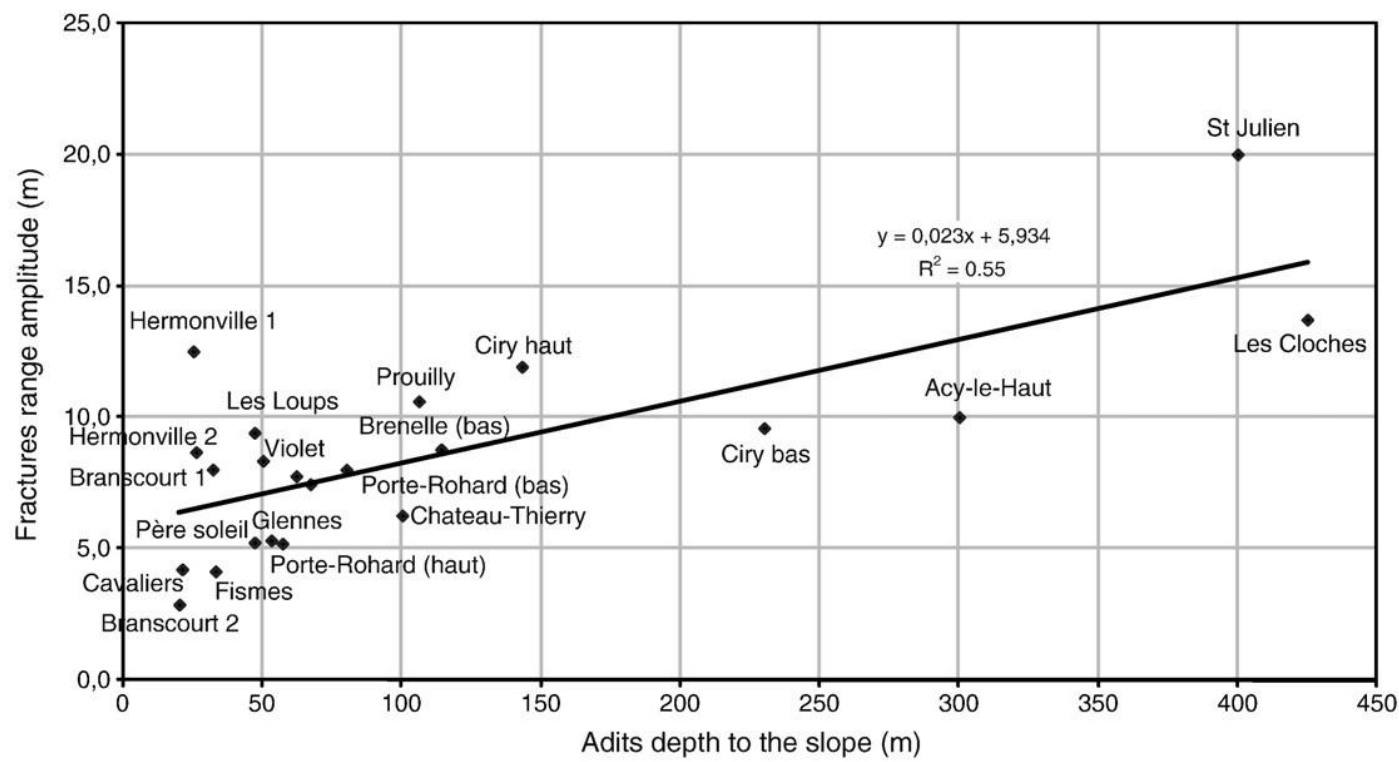

Fig. 3. Correlation between average spacing range of fracturing and adits horizontal depth (length to the slope).

The orthogonal spatial organization of the fractures determines a break-up device of decametric limestone blocks at headlands or interfluves. It is common to identify two main families of fractures in underground quarries (Rocher et al., 2003; Moiriat et al., 2005): those attributed to the mechanical distension of the slopes of the valley and those related to tectonic stress.

The aerial surveys were used to study the network of lineaments (Duprat, 1997). Their rendering highlights probable faults and possible normal or reverse faults, represented on geological maps, but which reflect the tectonic constraints:

The $\mathrm{N}^{\circ} 5^{\circ}$ orientation or Variscan faults include compression or transpression to sinistral strike-slip to the Eocene.

The $\mathrm{N} 105^{\circ}$ orientation is represented by relayed faults and distention faults end-cretaceous but inherited from the Hercynian or Permo-Triassic phase. This approach corresponds to the main basins of the study area (Marne, Aisne and Vesle upstream of Rheims and Automne River).

The $\mathrm{N} 125^{\circ}$ or Armorican orientation corresponds to compressive or transpressive with a dextral game in Thanetian. This direction corresponds to the main river side (Ardre, Vesle downstream Fismes or Ailette River).

Finally, the $\mathrm{N} 160^{\circ}$ orientation is associated with some extensional corridors with grabens. In our studied area, they are associated with lower order tributaries dependant on main hydrographic axis.

The timing of the hydrographic network on the tectonic axis does not allow differentiating by the orientations, the mechanical fractures of slackening tectonic fractures.

\subsubsection{Fractures spacing range and density of the fracture network}

The density of the discontinuities is not homogeneous in the study area nor in the underground quarries (Fig. 3). It tends to grow when approaching the slope. Indeed, the average distance between each fracture (spacing) grows from $2 \mathrm{~m}$ at the edge of the massif (Fismes, Branscourt) to over $20 \mathrm{~m}$ in the heart of the plateau (Courville, Bonneuil-enValois) $400 \mathrm{~m}$ from the slope. The density of cracks is particularly important in the east of the studied area (Hermonville) and appears to decrease towards the west concomitantly with the increase of the thickness of the Lutetian 
Devos, A., Fronteau G., Lejeune, O., Sosson, C., Chopin, E., and Barbin, V., 2010, Influence of geomorphological constraints and exploitation techniques on stone quarry spatial organisation. Example of Lutetian underground quarries in Rheims, Laon and Soissons areas. Engineering Geology, vol. 115. p. 268-275. doi:10.1016/j.enggeo.2010.05.004.

The timing of hydrographic network on tectonic is found, but the spatial organization of such fractures and their density responds to mechanical constraints near the slopes (distension fractures) inherent in the decompression of the limestone massif at the level of valleys.

\subsubsection{Fractures aperture}

The slackening is then manifested by the enlargement of fracture apertures on the periphery of the limestone massif. At the heart of the plateaus, the lips of the fractures are parallel and spaced less than $1 \mathrm{~cm}$ apart. However, on a slope or at the edge of the massif, fractures are closed at the floor and open at the sky of the galleries. The distribution of fractures aperture in the underground quarry of Acy (Fig. 4), conducted on 249 measurements, shows that $70 \%$ of fractures are opened up with an average width of $17 \mathrm{~cm}$ which hide a large spatial disparity.

The fractures aperture may exceed $1 \mathrm{~m}$, which shows a typical lateral spreading of tertiary plateau (Veyret et al., 1998) and nontectonic stress. Fracture distension is so large that they become penetrable. It then reaches the wall of the Lutetian where glauconitic sands are unstructured (Prouilly). The weight of limestone slabs has a consistent compression and crushing of sands which are injected in cracks distension. These decametrical blocks sink into the crumbly sands of upper Ypresian by gravity and density contrasts. On the slopes, the lateral spreading is accelerating because of mowing layers (gravitational sagging).

\subsubsection{Cambering and mass movement}

The Lutetian layer tends to bend in the direction of the slope, it determines local dip non-compliant ("apparent dip") to the general structure and to the opening of fractures. Cambering of slopes is highlighted by the geometry of particular banks (reference banks) observed underground and measured with a theodolite (Table 1). In certain locations, values of aparent dip may reach $30^{\circ}$. These underground observations are confirmed by the information of geological surveys where it is common to note differences in altitude of 5 to $10 \mathrm{~m}$ for a same reference level, between data from the tray and observations on the edges of it (Laurain et al., 1976).

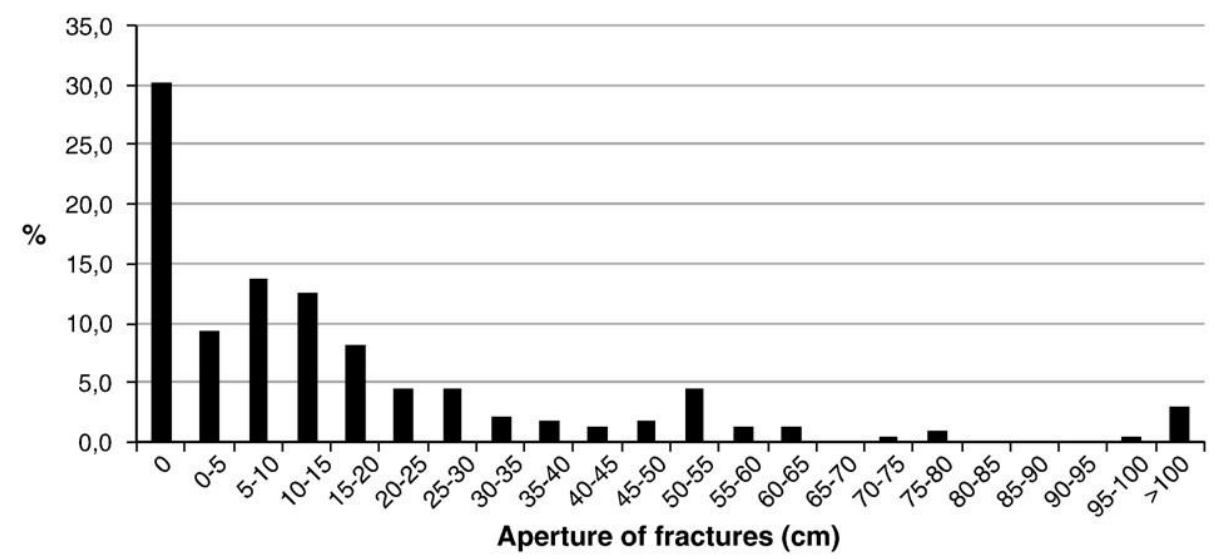

Fig. 4. Distribution of fractures aperture in the underground quarry of Acy.

The centimetric gap of reference banks on both sides of the fractures also shows compaction of limestone blocks that tend to sink into the underlying upper Yprésian sands. On the edge of the slope, under the influence of gravity, the gap is sometimes metric (Devos et al., 2008) which illustrates the birth of sliding blocks. The fractures network is organized in stairs, affected by small 'grabens' which also reflect the mechanical distension of limestone in the periphery of the plateaus.

The orthogonal spatial organization of the fractures determines the formation of limestone blocks whose size depends on the density of fractures. At the edge of the plateaus, blocks are ten square meters when they reach one hundred square meters in the hearth of the plateau. This "calving" of limestone blocks layered on crumbly sands (upper Ypresian) or plastics (“Argiles de Laon") generates landslides on the slopes (Van den Eeckaut et al., 2007, 2010). 
Devos, A., Fronteau G., Lejeune, O., Sosson, C., Chopin, E., and Barbin, V., 2010, Influence of geomorphological constraints and exploitation techniques on stone quarry spatial organisation. Example of Lutetian underground quarries in Rheims, Laon and Soissons areas. Engineering Geology, vol. 115. p. 268-275. doi:10.1016/j.enggeo.2010.05.004

The permeability of the limestone fissures is considerably accentuated which amplifies the infiltration in upper Ypresian sands. This made a porous aquifer whose aquiclude is represented by Ypresian clays. The creeps of clays, supplied by the upper Ypresian aquifer drown area causes major shifts whose gliding plane affects the Lutetian, the upper Yprésian and the lower Ypresian. This occurs on the surface by many benches and reversal of slopes in the event of rock slump.

1.1.5. Nature of fractures infilling and geomorphological processes linked

The fractures are generally filled by indigenous (in-situ alteration) and allogenic (withdrawal) materials (Blondeau, 1970; Pellegrin and Salomon, 2001). The statements on the 249 fractures at Acy show that only 35\% of fractures are not filled (Fig. 5). Each formation observed in the fractures is associated with a geomorphological process (Table 2). The total does not equal $100 \%$ because $15 \%$ of fractures have mixed fillings associated with two or three processes.

Table 1

Values of apparent dips measured on 4 sites in underground quarries.

\begin{tabular}{lllll}
\hline Sites & Bonneuil-en-Valois & Oeuilly & Branscourt & Hermonville \\
\hline Value of apparent dip & $18^{\circ}$ & $30^{\circ}$ & $15^{\circ}$ & $10^{\circ}$ \\
\hline
\end{tabular}

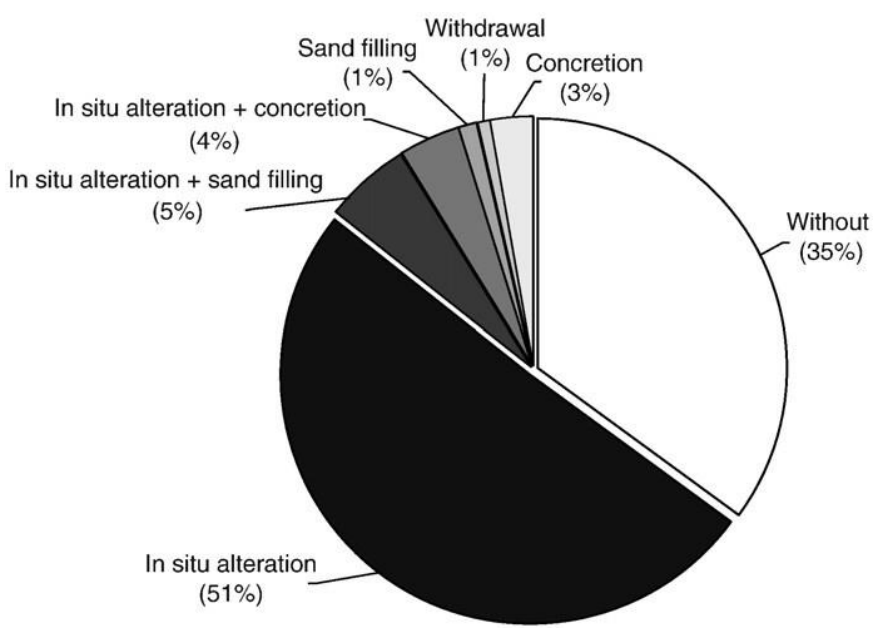

Fig. 5. Nature of fracture infilling in the underground quarry of Acy.

For the Acy area, at the west of the studied area (Soissonnais), the majority of fractures are filled with regolith (weathered rock). Decalcification clays, composed of complex associations dominated by smectites (montmorillonite), are found in the fractures whose edges are altered. The measured concentrations of $\mathrm{CaCO}_{3}$ in enclosing limestone in the center of alterite is more than $70 \%$ to less than $1 \%$ while the organic carbon remains below 1\%. This in situ alteration (Vergari and Quinif, 1997; Quinif, 1999a,b; Quinif and Quinif, 2002; Havron et al., 2007) characterized open but also closed fractures (pseudo-endokarst).

However, at the east of the study area (Tardenois, Rheims area), $80 \%$ of fractures are usually filled with limestone heterometric blocks wrapped in an unstructured clay matrix (mainly with palygorskite or smectites). This heterogeneous formation results from a withdrawal of clays, marls and continental limestones of the Upper Lutetian. 
Devos, A., Fronteau G., Lejeune, O., Sosson, C., Chopin, E., and Barbin, V., 2010, Influence of geomorphological constraints and exploitation techniques on stone quarry spatial organisation. Example of Lutetian underground quarries in Rheims, Laon and Soissons areas. Engineering Geology, vol. 115. p. 268-275. doi:10.1016/j.enggeo.2010.05.004.

Some local fractures are filled with sands with a horizontal stratification structure whose binocular examination and mineral spectrum shows that they come from the overlying formations of Auversien. Their bedding in rhythmites indicates a slow settling regime drowned (flooded karst).

These processes of chemical weathering, karstification and withdrawal represent a mechanical constraint in the exploitation of limestone.

\section{Spatial organisation of underground quarries and exploitation techniques}

Underground quarries topographies can represent their spatial organization, which is associated with mining techniques. These are very diverse in the studied area. There are three areas where technologies seem to be uniform, the area of Rheims, the area between Rheims and Fismes and the west (Soissons and Valois).

\subsection{The east of studied area (near Rheims)}

In this area, the fracturing network is the factor which determined the extraction method for obtaining stones, with dismantling technique. The fractures were used by the quarrymen in their working methods. The quarries are situated on top of Middle Lutetian, they are small (less than one hectare) with galleries of less than $2.5 \mathrm{~m}$ high.

Table 2

Nature of fracture infilling and associated processes (underground quarry of Acy).

\begin{tabular}{|c|c|c|c|c|}
\hline Infilling lithology & Clays and sands & Bedded sands & Heterometric blocks & Speleothems \\
\hline Structure & Vertical & Horizontal & Heterogen & Vertical \\
\hline Processus & In-situ alteration & Karst (flooded) regime) & Withdrawal & Karstic concretioning (vadose regime) \\
\hline$\%$ & 78 & 2 & 1 & 4 \\
\hline
\end{tabular}

Topographies made on 11 quarries and the distribution diagrams of the directions of the galleries show that most of the quarries are organized in space by fracturing network (Fig. 2). From an aerial excavation, the galleries follow major fractures (Fig. 6), that let the quarrymen economize cutting slits. Therefore, the galleries hedge and follow the contour lines. Like the fractures, they are close to the slope in that they intersect several times, which determines 5 entries at the big quarry of Glennes. The orthogonal directions galleries are due to the widening of shallow rooms or workshops perpendicular to the main gallery, which is following a fracture. For example, at Glennes (quarry of Grenades), the main galleries are oriented at $50^{\circ}$ and the main fractures are following the orthogonal $130^{\circ}$ direction. At Prouilly, main fractures are oriented in 2 principal directions: $120^{\circ}$ and $30^{\circ}$ to $40^{\circ}$, and galleries are following the same major orientations. Sites of 'spur' or projecting between two tributary valleys are preferred by quarrymen because the orthogonal fracturing network of mechanical distension minimizes the work of stone cutting. At Prouilly, valleys are oriented at $40^{\circ}$ and at $120^{\circ}$ which correspond to main fractures and quarrymen progress. At Romain, the diagram shows that $90 \%$ of the fractures follow valleys with 3 principal orientations: $20^{\circ}, 90^{\circ}$ and $130^{\circ}$.

The spatial organization of the exploitation is made by two or three parallel but irregular galleries, with side chambers leaving irregular mass residual pillars.

The tool traces show peak use,needle and spear. All the discontinuities of limestone are used to minimize cutting work (technique of dismantling). Thus, the base and the roof of extracted blocks lie within the stratification joints widened and extended by peak ("désouchevage") while the lateral sides are either cut ("défermage") or correspond to fractures. The vertical heterogeneity facies multiply extracted banks and the importance of the density of fracturing. This explains the extraction type used by quarrymen. In this area, at the borders of the slopes, a fracture may exist every $2 \mathrm{~m}$.

However, it has many disadvantages because quarrymen were concerned with safety regulations regarding the stability of the roof, which is manifested in many sinkholes, open to the surface (at Prouilly, we have topographied 14 sinkholes, 12 at the Mont-Chatté and 3 at Glennes big quarry).This technique also gives off a lot of waste (jams)that 
Devos, A., Fronteau G., Lejeune, O., Sosson, C., Chopin, E., and Barbin, V., 2010, Influence of geomorphological constraints and exploitation techniques on stone quarry spatial organisation. Example of Lutetian underground quarries in Rheims, Laon and Soissons areas. Engineering Geology, vol. 115. p. 268-275. doi:10.1016/j.enggeo.2010.05.004.

must be stored underground behind dry stone walls ("hagues") which determines a ratio of void volume and total volume low (below 70\%).

\subsection{The western study area (Soissonnais and Valois)}

In this area, thickness, uniformity of coarse limestone and lower distension, induces a mechanical method of extracting, more rationalized. Quarries are large (over one hectare at the surface) and the workings are at the heart of the plateau and part of the Verrines banks or limestones of Saint-Leu.

The distribution of gallery directions is less following fractures. Generally, a gallery perpendicular to the slope (access gallery) sinks in the heart of the plateaus over $100 \mathrm{~m}$ or $450 \mathrm{~m}$, to enter the exploitation site (Fig. 6). That prevents the periphery of the plateaus too marked by the mechanical distension.

The excavation site is rationally organized into rooms and pillars mining system and arranged according to specifications (Vassens, Bonneuil-en-Valois).

The mass residual pillars of the same size (minimum $3 \times 3 \mathrm{~m}$ ), cut in the limestone mass line up on a checkerboard to support the roof of the quarry. The gaps do not correspond to galleries but bay. This technique allows the obtaining important ratio of void volume of total volume (close to $90 \%$ ). Galleries or extraction pits allow the removing of stones at the surface by winch moved by horses.

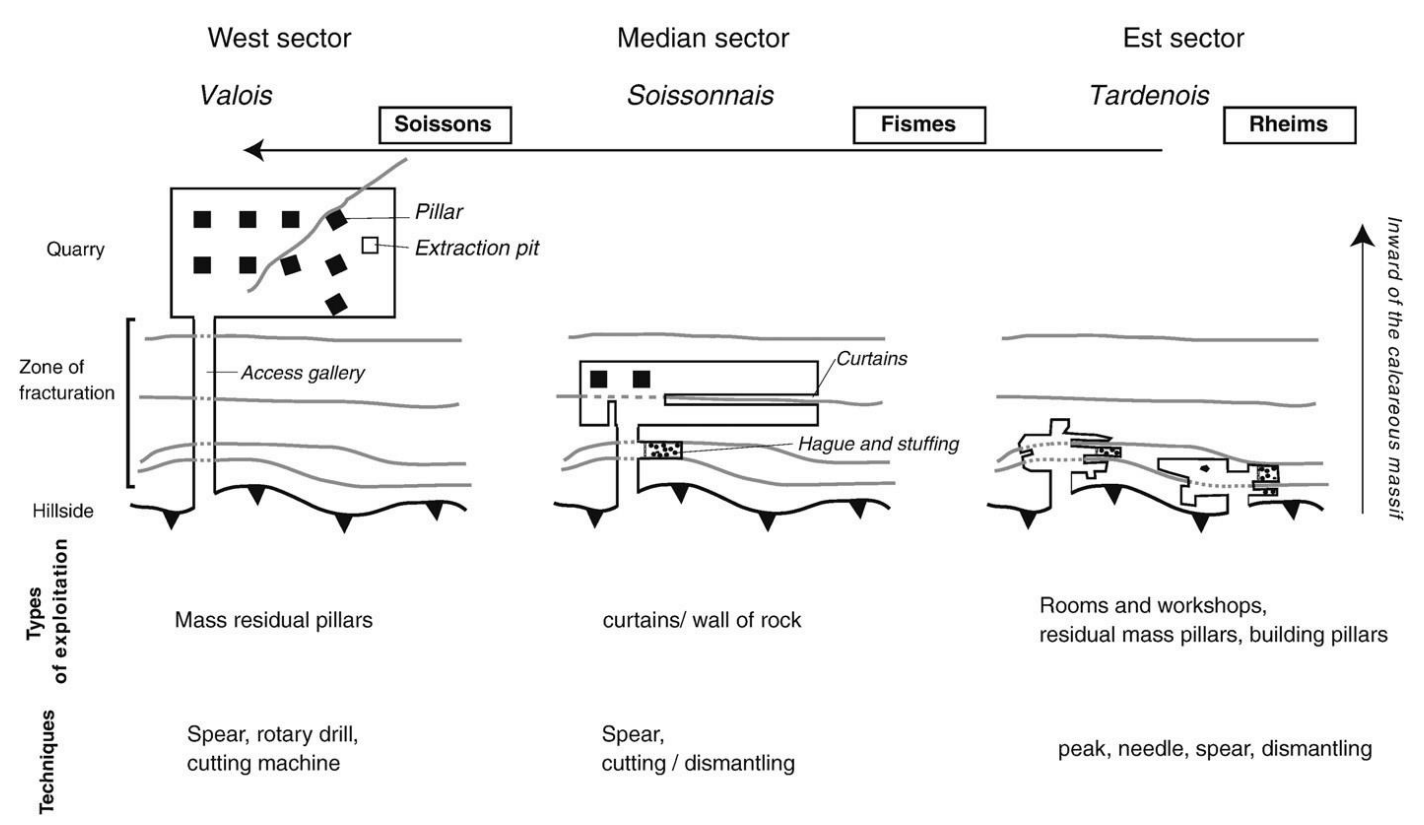

Fig. 6. Spatial organization and underground excavation techniques adopted in underground quarrying.

The limestone discontinuities are not yet used because it disturbs the pattern of exploitation. The fractures are avoided because they are associated with an alteration of geomaterials (ghost rock), to the karstification and withdrawal (Kaufmann and Quinif, 1999, 2002). The exploitation technique is cutting the stone, using spear, cutting machine or rotary drill.

\subsection{Mixed exploitation (between Soissons and Rheims or XIX century)}

Between Soissons and Rheims, the spatial organization of underground quarries is mixed because it includes both types of extraction presented above. Cutting and dismantling are used in the same quarry. 
Devos, A., Fronteau G., Lejeune, O., Sosson, C., Chopin, E., and Barbin, V., 2010, Influence of geomorphological constraints and exploitation techniques on stone quarry spatial organisation. Example of Lutetian underground quarries in Rheims, Laon and Soissons areas. Engineering Geology, vol. 115. p. 268-275. doi:10.1016/j.enggeo.2010.05.004.

There is a timing of galleries on fracturing network but farther from the slope. The exploitation is presented in the form of 3 or 4 relatively large and parallel galleries separated by a wall of rock untapped ('curtains'). At Ciry-Salsogne, $50 \%$ of galleries follow the main fractures (orientation of $\left.160^{\circ}\right)$ and the rest of the galleries directions $\left(140^{\circ}, 80^{\circ}, 70^{\circ}\right.$ and $50^{\circ}$ ) is independent of fracturing network. The fracturing network is entirely dependent of the incision of the Vesle river and of tributary valleys whose orientations are $40^{\circ}$ and $150^{\circ}$ (Fig. 2).

\section{Discussion}

Fronteau et al. (2010) have shown the importance of vertical and lateral variations of Lutetian limestone facies, which determines high spatial variability of petrophysical and petrographic parameters of Lutetian between Rheims, Laon and Soissons. Although, alone, geological factors do not explain the organization of underground quarries (Yilmazer, 1995). Indeed, fracturing (mechanical distension) related to incision of valleys equally determines the potential and constraints in the exploitation of limestone geomaterials.

The deposit of limestone geomaterials (Middle Lutetian) being under the cover of marl and continental limestone, outcrops in the valleys, as extraction proceeds. Fractures of distension are organized in space according to geotechnical constraints, between compression and distension, affecting plateaus. These constraints dictate strong spatial variations of density, amplitude, width or spacing, and geomorphological behavior of the fractures (BakunMazor et al., 2009).

Other factors may exist, which could explain the closure of the underground quarries of lutetian limestones. Economical and social reasons are to be considered (family exploitations at the east, minimum of one quarry in each village). If reconstructions post WW1 had favoured the reopening of these quarries, it would have been for a short time.

A study of micro fracturing network may allow us to see more exactly tectonical constraints and better differentiate the origins of fractures (mechanicals or tectonics) (Rocher et al., 2003).

\section{Conclusion}

The geomophological constraints and the fracturing network, take a fundamental part on underground exploitation (and desertion) of the Lutetian limestones.

The outcrops are numerous. The geological cover layered on inferior and middle Lutetian do not allow aerial exploitation because when the quarries where opened (XIXth century), the technical means were rudimentary (peak).

Moreover, the important fracturing network, depending on major tectonic axis and valley incisions (Cerepi, 2002; Moiriat et al., 2005), has been used by the quarrymen to economize cutting slits. A part of the underground galleries has followed the discontinuities parallel to the slopes, and an orthogonal progress direction has been used too. Before mechanization of underground exploitation, the galleries were located at the periphery of the slopes. Quarries were short and anarchic. Rapidly, because of the high density of fractures due to the distension of slopes, at the east of the studied area, underground quarries have been abandoned (Koca and Kincal, 2004).

At the west, as the Lutetian limestones were thicker and uniform, the exploitation lasted longer (best profitability) and with mechanical progress, the quarrymen were able to work at the heart of the plateau with better safety conditions. Underground exploitations were large and rational. Only fracture fillings could disturb the exploitation, or be dangerous for the quarrymen (brutal sewage of fillings).

Acknowledgements : The authors would like to thank Sarah Winsper for her kind help in the translation.

\section{References}

Bakun-Mazor, D., Hatzor, Y.H., Dershowitz, W.S., 2009. Modeling mechanical layering effects on stability of underground openings in jointed sedimentary rocks. International Journal of Rock Mechanics and Mining Sciences 46 (2), 262-271.

Blary, F., Gely, J.-P., Lorentz, J., Obert, D., Vire, M., 2004. La pierre à Château-Thierry, de la carrière à la ville, Ed. Ass. Patrimoine Vivant, Château-Thierry, 99 pp. 
Devos, A., Fronteau G., Lejeune, O., Sosson, C., Chopin, E., and Barbin, V., 2010, Influence of geomorphological constraints and exploitation techniques on stone quarry spatial organisation. Example of Lutetian underground quarries in Rheims, Laon and Soissons areas. Engineering Geology, vol. 115. p. 268-275. doi:10.1016/j.enggeo.2010.05.004.

Blondeau, A., 1970. Le calcaire grossier du Bassin de Paris, Bull. du BRGM (deuxième série), section II, 4, pp. 7-17.

Cerepi, A., 2002. Analyse quantitative de l'hétérogénéité de la fracturation: application aux carrières souterraines. CR Geosciences 334, 163-170.

Devos, A., Sosson, C., Lejeune, O., Fronteau, G., 2008. Rôle des contextes géomorphologiques et géologiques dans l'abandon des carrières de pierre du Lutétien autour de Reims, Pierres du patrimoine européen. Economie de la pierre de l'antiquité à la fin des temps modernes, Editions du comité des Travaux Historiques et Scientifiques, Paris, pp. 423-432.

Dolfini, L., 1920. Recherches de carrières. Reims, Monuments historiques, Cathédrale de Reims, Architecte en Chef : Deneux, Ministère de l'instruction publique et des Beaux-Arts. (25pp.).

Duprat, M., 1997. Modèle tectono-sédimentaire des dépôts paléogènes dans le Nord-Est du Bassin de Paris : conséquences sur la géométrie du toit de la craie. Annales de la Société Géologique du Nord 5, 269-287.

Fronteau, G., 2000. Comportements telogénétiques des principaux calcaires de Champagne Ardennes, en relation avec leur faciès de dépôt et leur séquençage diagénétique, Thèse de l'Université de Reims Champagne-Ardenne, 302 pp.

Fronteau, G., Pascal, A., Barbin, A., 2002. Caractérisation de la Pierre de Courville (Lutétien, Marne, France) - relation entre diagenèse et propriétés pétrophysiques. Géologie de la France 4, 51-59.

Fronteau, G., Moreau, C., Thomachot-Schneider, C., Barbin, V., 2010. Variability of some Lutetian building stones from the Paris Basin, from characterisation to conservation. Engineering Geology 115 (3-4), 158-166 (this issue).

Gely, J.-P., 1996. Le Lutétien du Bassin de Paris : de l'analyse séquentielle haute résolution à la reconstitution paléogéographique. Bulletin d'Information des géologues du Bassin de Paris 34 (4), 3-27.

Gely, J.-P., 1998. Le Lutétien du Valois et du Laonnois. Bulletin d'Information des géologues du Bassin de Paris 35 (3), 16-19.

Gely, J.-P., Lorenz, J., Merle, D.S.D., 2009. Le Lutétien, Géochronique, Dossier n¹09, pp. 15-47.

Havron, C., Baele, J.-M., Quinif, Y., 2007. Pétrographie d'une altérite résiduelle de type «fantôme de Roche ». Karstologia 49, 2532.

Jaillet, S., Depaquis, J.-P., Herbillon, C., 2002. Le karst et les carrières souterraines du Barrois : un siècle et demi de relations Hommes/Milieu. Karstologia 40 (2), 27-38.

Kaufmann, O., Quinif, Y., 1999. Cover-collapse sinkholes in the Tournaisis area, southern Belgium. Engineering Geology 52, 1522.

Kaufmann, O., Quinif, Y., 2002. Geohazard map of cover-collapse sinkholes in the Tournaisis area, southern Belgium. Engineering Geology 65, 117-124.

Koca, M.Y., Kincal, C., 2004. Abandonned stone quarries in and around the Izmir city centre and their geo-environmental impacts inTurkey. Engineering Geology 756, 49-67.

Lachaux, G., 2005. Les creutes - Chemin des Dames et Soissonnais, L'encrier du poilu. (291 pp.).

Laurain, M., Guerin, H., Barta, L., Magniant, D., Gianordoli, M., Parent, R., Duhermael, G., 1976. Carte géologique de Fismes et notice explicative. BRGM. Orléans, 34pp.

Mauvais, L., 2004. Souterrains de l'Aisne, Carrières de Laon, Saint-Gobain, Vassens, Prémontré, Danisy, Passé Simple, Ed. Alan Sutton, $222 \mathrm{pp}$.

Moiriat, D., Potherat, P., Durville, J.-L., Bebien, J., 2005. Observations sur la fracturation liée à l'incision d'une vallée, Carrière souterraine des Brillants (Hauts-de-Seine).

Bulletin des Laboratoires des Ponts et Chaussées 258-259, 3-14.

Montagne, D., 1998. les souterrains de Laon, Nord Patrimoine Editions. (128 pp.).

Pelizza, S., Oreste, P., Peila, D., Oggeri, C., 2000. Stability analysis of a large cavern in Italy for quarrying exploitation of a pink marble. Tunneling Underground Space Technology 15, 421-435.

Pellegrin, J.-C., Salomon, J.-N., 2001. Hydrocompaction, dissolution, suffosion et soutirage - contribution à la formation des dépressions fermées. Karstologia 37, 54-56.

Pomerol, C., Feugueur, L., 1974. Bassin de Paris - Ile de France - Pays de Bray, Guides géologiques régionaux, Ed. Masson, 215 pp. Quinif, Y., 1999a. Dissipation d'énergie et adaptabilité dans les systèmes karstiques. Karstologia 31, 1-11.

Quinif, Y., 1999b. fantomisation, crypto-altération et altération sur roche nue, le triptyque de la karstification, étude de géographie physique, travaux de 1999, suppl. XXVIII, CAGEP, Univ. de Provence, pp. 159-164.

Quinif, Y., Quinif, G., 2002. Méthodes et éléments de cartographie d'un paléokarst - l'exemple de la carrière du Clypot (hainaut, Belgique). Karstologia 39, 1-8.

Rocher, M., Baize, S., Jaillet, S., Cushing, E.M., Lozach'h, Y., Lemeille, F., 2003. Quaternary stresses revealed by calcite twinning inversion: insights from observations in the Savonnières underground quarry (eastern France). C.R. Geosciences 335, 701708. 
Devos, A., Fronteau G., Lejeune, O., Sosson, C., Chopin, E., and Barbin, V., 2010, Influence of geomorphological constraints and exploitation techniques on stone quarry spatial organisation. Example of Lutetian underground quarries in Rheims, Laon and Soissons areas. Engineering Geology, vol. 115. p. 268-275. doi:10.1016/j.enggeo.2010.05.004.

Sosson, C., Devos, A., Lejeune, O., Marre, A., 2009. Contribution to the study of underground quarries : the underground quarry at Glennes (Aisne-France). 4th International Symposium on Archaeological Mining History book, Reichelsheim/Odenwald (Germany), Jacquo Silvertant MA, Institute Europo subterranea, pp. 14-25.

Van den Eeckaut, M., Poesen, J., Dusar, M., Martens, V., Duchateau, Ph., 2007. Sinkole formation above underground limestone quarries: a case study in South Limburg (Belgium). Geomorphology 91, 19-37.

Van den Eekhaut, M., Marre, A., Poesen, J., 2010. Comparison of two landslide susceptibility assessments in the ChampagnArdenne region (France). Geomorphology 115, 141-155.

Vergari, A., Quinif, Y., 1997. Les paléokarsts du Hainaut. Geodinamica Acta 10, 175-187.

Veyret, Y., Ballais, J.-L., Marre, A., Mietton, M., Miossec, A., Morin, S., Valadas, B., 1998. L'érosion entre nature et société, S.E.D.E.S., Coll. DIEM no. 22, Paris. (344 pp.).

Yilmazer, I., 1995. Engineering geologic factors in the design of a large underground structure in a tuff sequence in Cappadocia. Engineering Geology 40, 235-241. 